J. Product. \& Dev., 19(3):363 - 372(2014)

\title{
ANTIBACTERIAL ACTIVITY OF DIFFERENT EXTRACTS OF CYANOBACTERIA.
}

\author{
Sabha M. EL-Sabagh ${ }^{1}$;agaa A. Hamouda ${ }^{2}$;hada W. Abo-Elsoud ${ }^{3}$ \\ and Abeer N.Hendawy \\ 1,3,4Botany Department, Faculty of science, Menufiya University, Egypt. \\ Microbial Biotechnology Department \\ 2Genetic Engineering and Biotechnology Research Institute (GEBRI) \\ University of Sadat City, Egypt.
}

\begin{abstract}
The concept of biological control for health maintenance has received worldwide attention during the last few decades. Therefore, the main objective of this work was to look for active substances that could be used as antibacterial agents. To achieve this target different extracts (Methanol, Petroleum ether, Dichloromethan, Ethyl acetate) fromAnabaena oryzae,were examined. The algal extracts were tested in vitro for itsantibacterial effects against three Gram +ve and Gram -ve bacteria (Escherichia coli, Bacillus cereus, Klebsiella pneumonia) using Agar well diffusion method and concentrations from $50 \mathrm{mg}$ up to $150 \mathrm{mg}$ were taken tested bacteria showed inhibition in growth by these extracts.

Conclusively, the results obtained in the present investigation clearly suggest that the production of pharmacologically products from Aphanocapsasp, could represent a viable and environmentally friendly alternative to reduce the use of synthetic chemicals because of their unintended side effects for the control of pathogenic microorganisms.
\end{abstract}

Key words:Antibacterial, cyanobacteria, methanol extract.

\section{INTRODUCTION}

Pharmaceutical drug discoveries, for most of the past 40 years, have depended heavily on the process of empirically screening of large number of pure compounds to provide new leads ,Cyanobacteria are a very old screening method of cyanobacteria for antibiotics, and other pharmacologically active compounds have recently received considerable 
attention (Borowitzka, 1995). Algae are rapidly proving to be an extremely important source of biologically active secondary metabolites which could be used for the biological control of pathogens. Cyanobacteria (blue green algae) are one of the richest sources of biomedical relevant compounds with extensive therapeutic pharmaceutical applications (Tan, 2007; Gademann and Portmann, 2008; Martins et al., 2008).Various strains of cyanobacteria are known to produce intracellular and extracellular metabolites with diverse biological activities such as antibacterial (Mundt et al.,2003; Raoet al., 2007; Kaushik and Chauhan, 2008), antifungal (MacMillan et al., 2002), cytotoxic (Luesch et al., 2000).

Most species of cyanobacteria are free-living, freshwater, marine or terrestrial which could be planktonic, or benthic and comprise major components of microbial mats. There are many reports on the inhibition of human pathogens by algal extracts. Research to identify antimicrobial compounds produced by microalgae against human pathogens as well as other pathogens, has recently received considerable attention as a new source of novel antimicrobial substances (Ladyginaet al., 2006). Certain systematic groups of microorganisms are characterized by specific composition of intracellular hydrocarbons; in particular, cyanobacteria are unique in their ability to produce 7 and 8-methyl heptadecanes (Ladyginaet al., 2006). Ethyl acetate extract of Spirulenaplatensis consisted of heptadecane and tetradecane which can inhibit some Gram +ve and Gram -ve bacteria and Candida albicans (Ozdemiret al., 2004). El-Sheekhet al., (2006) showed that phenolic compound from Nostocmuscorum exhibited antagonistic activity against Gram +ve and Gram -ve bacteria. Ghasemi et al., (2004) isolated substances belonging to groups of peptides, polypeptides, amides and alkaloids from Fischerellaambigua. Anabaena $s p$. produce a number of bioactive compounds, mostly lipopeptidases that have antibiotic, antialgal, anticancer, anti-inflammatory, cytotoxic and enzyme-inhibiting effects (Burjaet al., 2001; Fujiiet al., 2002). Oscillatoria $s p$. can produce fatty acids, tetraamine, spermine and piperazine derivatives which show antimicrobial activity (Mundt et al., 2003; Shanab, 2007). Thillairajasekar et al., (2009) showed the presence of fatty acids from hexane and ethyl acetate extract of Trichodesmium erythraeum exhibited antimicrobial activity. These developments and the associated increase in bacterial infections intensified the search for new, safer, and more efficacious agents to combat serious bacterial infections.

Therefore, this study was designed to investigate the antibacterial activity of cyanobacterium species Anabaena oryzaeand phytochemical analysis for it's antibacterial active extract. 


\section{MATERIALS AND METHODS}

\section{Isolation and Purification of cyanobacteria:}

Cyanobacterium, Anabaena oryzae, was isolated from soil. Isolation and purification of cyanobacteriawas done according to the method described by Rippka, (1988). Cyanobacteria wereisolated after repeated light migrations on solid BG11.

\section{Cultivationof cyanobacteria:}

Cyanobacteria were grown in Erlenmeyer flasks, $(250 \mathrm{ml})$ on liquid BG11 medium in axenic conditions. The cultures were incubated at the room temperature $\left(25 \pm 2^{\circ} \mathrm{C}\right)$ and a light intensity 2500 lux provided by cool, and white, fluorescent tubes under continuous illumination.

\section{Harvesting the cyanobacteria :}

Cyanobacterial cells were collected by centrifugation in the exponential growth phase (after 12 days), the pellets were washed with distilledwater and dried in oven at $60^{\circ} \mathrm{C}$.

\section{Preparation of cyanobacterium extract:}

$0.1 \mathrm{gm}$ of cyanobacteriumwas soaked in petroleum ether for $48 \mathrm{~h}$ and filtrated theresidues were soaked again in petroleumether for $48 \mathrm{~h}$ and filtrated. The precipitate was soaked in Dichloromethane for $48 \mathrm{~h}$ and repeated after $48 \mathrm{~h}$ soaked and filtrate and then by methanol. The filtrate was taken and Concentrated in vacuum until drying. The concentrated residue re-dissolved in $2 \mathrm{ml}$ dimethylsulphoxide (DEMTHO) to form different concentration $(50,100,150 \mu \mathrm{g} / \mathrm{ml})$. DEMTHO is used as control.

\section{Microbial indicators and growth conditions}

Gram +ve and Gram -ve bacteria were used in this study. Escherichia coli, klebsiella pneumonia (Gram -ve), Bacillus cereus (Gram +ve). Bacterial strains were kindly provided from Microbiology Laboratory, Botany Department, Faculty of Science, Tanta University, Egypt. All bacterial strains were maintained on nutrient agar slants and incubated at $30^{\circ} \mathrm{C}$. Bacterial biomass was prepared by inoculating $100 \mathrm{ml}$ of nutrient broth medium. Bacterial cultures were shaken $(250 \mathrm{rpm})$ at $30^{\circ} \mathrm{C}$ for $24 \mathrm{~h}$. Different inoculates were used at a logarithmic phase of growth.

\section{Testing antibacterial activity by the agar-well diffusion method}

The antagonistic activity of the extract of cyanobacterial cells was determined using cut-diffusion technique in which cut $(5 \mathrm{~mm})$ was 
punched upon the surface of agar plates previously inoculated with each of the above mentioned indicator strains. Each well bottom was sealed with two drops of sterile water agar. About $100 \mathrm{mg}$ of algal extract were transferred into each well. Wells loaded with the extracting solvents were used as controls; plates were then incubated at $37^{\circ} \mathrm{C}$ for $24 \mathrm{~h}$. After incubation, the diameters of the inhibition zones were measured with calipers and the results were recorded in mm (Attaie et al., 1987). All tests were performed under sterile conditions in duplicate and repeated three times.

\section{Electron microscopic examination:}

In order to visualize the morphological changes in the bacterial cells after treatment with the methanol extract of Anabaena oryzae, scanning electron microscope studies were carried out. Bacterial cells were harvested, washed with phosphate buffer and fixed with $2 \%$ glutraldehyde followed by $1 \%$ osmium tetroxide. After completion of fixation, samples were washed in buffer solution and the washed samples were dehydrated in ascending order of ethanol concentrations. The samples were dried completely and finally coated with gold in JEOL-JSM 5300, The Scanning Electron Microscope for samples, Using SEM Model Quanta 250 FEG (Field Emission Gun) attached with EDX Unit (Energy Dispersive X-ray Analyses), with accelerating voltage $30 \mathrm{~K} . \mathrm{V}$., magnification $14 \mathrm{x}$ up to 1000000 and resolutionat the ministry of petroleum the Egyptian mineral resources authority central laboratories sector.

Statistical analysis:

Each single treatment was replicated three times and the meanvalue \pm standard error was considered.

\section{RESULTS:}

\section{Antibacterial activities of cyanobacterial extract}

The results showed that methanol extracts notablyinhibited nearly the whole panel of the tested bacteriawith the widest inhibition zone (17.3 $\mathrm{mm})$ against Escherichia coli, and smaller inhibition zone $(15.3 \mathrm{~mm})$ against Klebsiella pneumonia, and no inhibition zone against Bacillus cereus (Table 1 ).

\section{Electron microscopic examination:}

Electron microscopic examination ofEscherichia coli, Bacilluscereus, klebsiella pneumoniabefore and after treatment with methanol extract of 
Anabaena oryzae, demonstratedmorphological alteration and they weregreatly transformed by the effect of algal extractas shown in Figure 1.

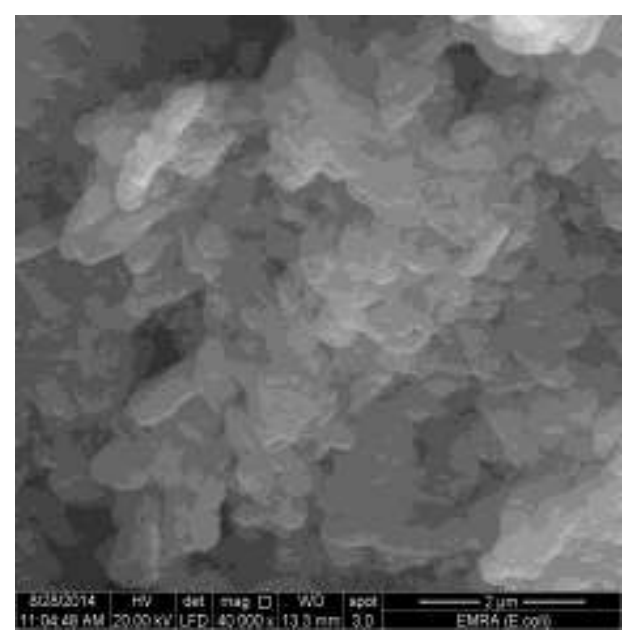

E.coli treated with algal extract

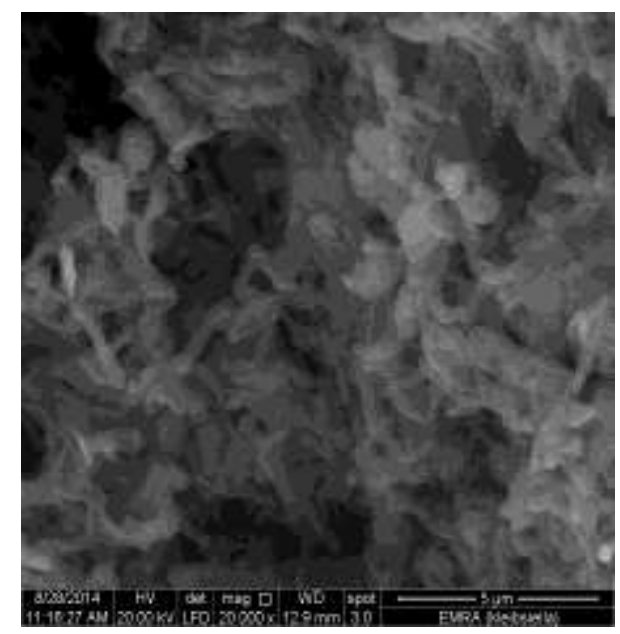

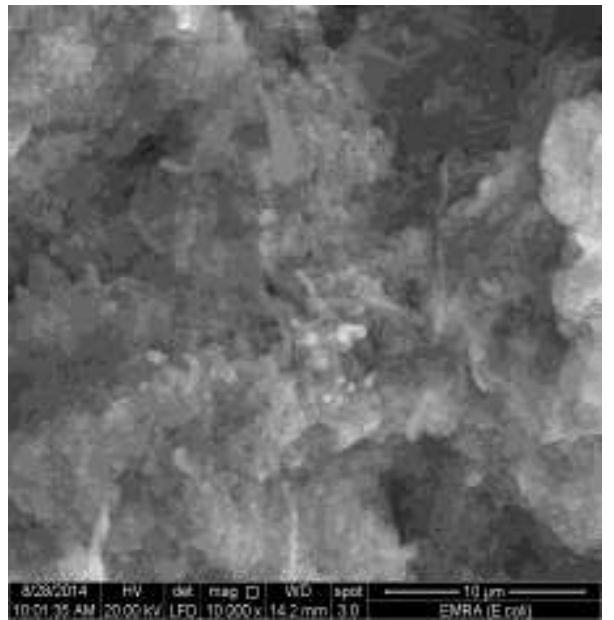

E.coli untreated with algal extract

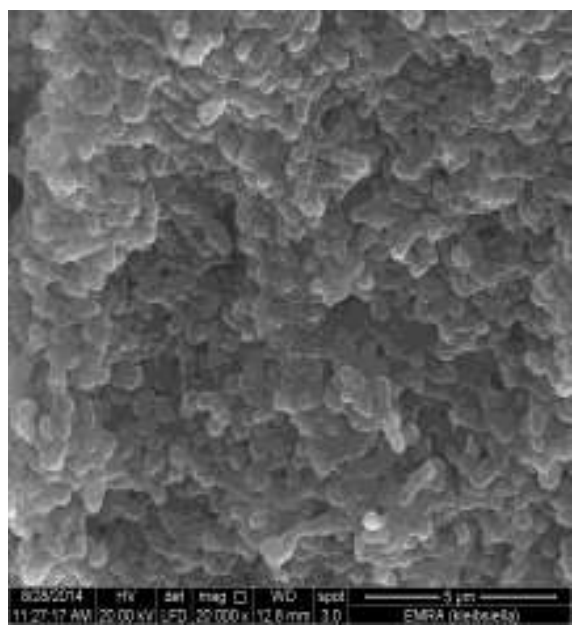

K. pneumonia treated with algal extract $K$. pneumonia untreated with algal extract 


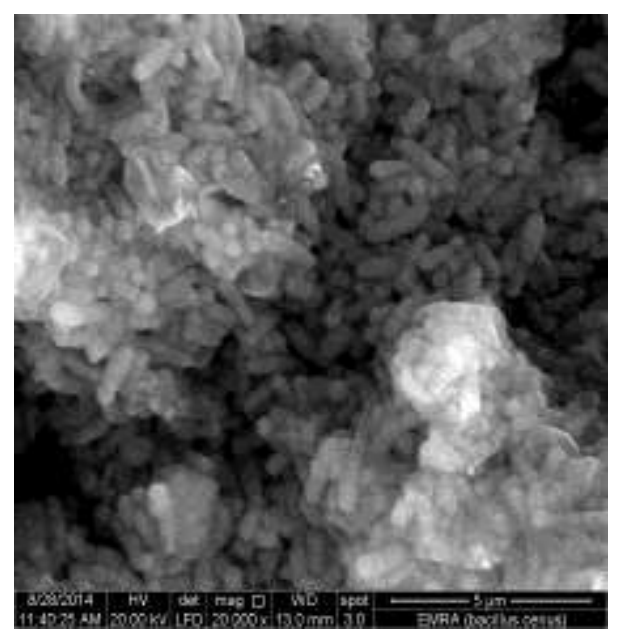

B. ceriustreated with algal extract

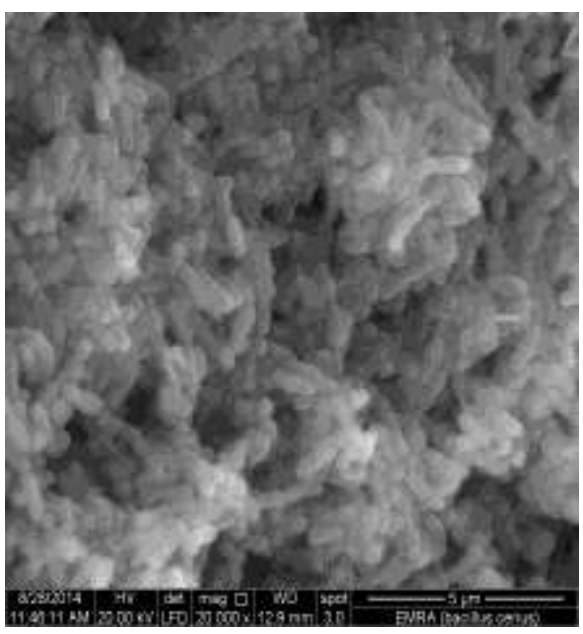

B. ceriusuntreated with algal extract

Figure (1): Electron microscopic examination ofEscherichia coli,Bacillus cereus, Klebsiella pneumonia before and after treatment with methanol extract of Anabaena oryzae.

\section{DISCUSSION:}

The goal in this study is to reveal the biological production of bioactive compounds by some cyanobacterial species. This study confirms that the methanol extract of cyanobacterial species have high activities against the tested microorganisms. The cluster analysis showed that, not all the target strains tested were equally susceptible to antibacterial metabolites produced from cyanobacterial species. These differences could be attributed to the strain of bacteria used could affect the results significantly (Philip et al., 2009). Our results are in agreement with Piccardi et al. (2000) who evaluated 50 Nostoc isolates from different habitats for their activity against two fungi (Penicilliumexpansum and Rhizoctoniasolani), and three bacterial species (Agrobacterium vitis, Escherichia coli and Staphylococcus epidermis and Artemiamauplii). The screening has shown that 24 of the isolates showed activity against at least one of the target organisms. it can be concluded that algal activity against Gram -ve bacteria was common as well as against Gram +ve and the tested fungi. These results go in harmony with those obtained by Feiet al. (2002);Walters et al. (2003) and Ghazalaet al. (2004) in their studies against Gram +ve, Gram -vebacteria and pathogenic fungi.The ability to 
produceagents may be significant not only as a defensive mechanism for the algal strains but also as a good source of the new bioactive compounds from a pharmaceutical point of view.

Conclusively, the results obtained in the present investigation clearly suggest that the production of pharmacologically products from Aphanocapsasp, could represent a viable and environmentally friendly alternative to reduce the use of synthetic chemicals because of their unintended side effects for the control of pathogenic microorganisms.

\section{REFERENCES}

Attaie, R.; Whalen, J.; Shahani, K.M.; Amer, M. A. (1987). Inhibition of growth of S. aureus during production of Acidophilus yogurt. $J$. Food Prot., 50: 224-228.

Borowitzka, M. A. (1995). Microalgae as source of pharmaceuticals and other biologically active compounds. J. Appl. Phycol., 7: 3-15.

Burja, A.M.; Banaigs, B.; Abou-Mansour, E.; Burgess, G.; Wright, C. (2001). Marine cyanobacteria-a prolific source of natural products. Tetrahedron, 57: 9347-9377.

El-Sheekh, M.M.; Osman, M.E.H.; Dyab, M.A.; Amer, M.S. (2006).Production and characterization of antimicrobial active substance from the cyanobacterium Nostocmuscorum. Environ. Toxicol. Pharmacol., 21: 42-50.

Fei, T.D.; Jing, W.R.; Ming, L.; Xin, L.Y. (2002). Studies on chemical compositions and antimicrobial activity of volatile oil of Dictyophorae chinovolvata. Mycosystema, 21: 228-233.

Fujii, T.; Nakao, F.; Shibata, Y.; Shioi, G.; Kodama, E.; Fujisawa, H.; Takagi, S. (2002). CaenorhabditiselegansPlexinA, PLX-1, interacts with trans membrane semaphorins and regulates epidermal morphogenesis. Development, 129: 2053-2063.

Ghasemi, Y.; Tabatabaei, Y., Shafiee, A., Amini, M.; Shokravi, S.H.; Zarrini, G. (2004). Parsiguine, Anovel antimicrobial substance from Fischerellaambigua. Pharmacol. Biol., 2: 318-322.

Gademann, K.; Portmann, C. (2008). Secondary metabolites from cyanobacteria: complex structures and powerful bioactivities. Curr. Org. Chem., 12: 326-341.

Kaushik P, Chauhan A (2008). In vitro antibacterial activity of laboratory grown culture of Spirulinaplatensis. Ind. J. Microbiol.,pp 48. 
Luesch, H.; Yoshida, W.Y.; Moore, R.E.; Paul, V.J., Mooberry, S.L. (2000). Isolation, structure determination and biological activity of Lyngbyabellin A from the marine Cyanobacterium Lyngbyamajuscula. J. Nat. Prod. 63: 611-615.

Ladygina, N.; Dedyukhina, E.G. and Vainshtein, M.B. (2006). A review on microbial synthesis of hydrocarbons, Process Biochemistry, 41: 1001-1014.

MacMillan, J.B.; Ernst-Russell, M.A.; De Roop, J.S.; Molinski, T.F. (2002). Lobocyclamides A-C, lipopeptides from a cryptic cyanobacterial mat containing Lyngbyaconfervoides. J. Org. Chem. 67: 8210-8215.

Mundt, S.; Kreitlow S, Jansen, R. (2003). Fatty acids with antibacterial activity from the cyanobacterium Oscillatoriaredekei HUB 051. J. Appl. Phycol. 15: 263-267.

Martins, R.F.; Ramos, M.F.; Herfindal, L.; Sousa, J.A.; Skærven, K.; Vasconcelos, V.T. (2008). Antimicrobial and cytotoxic assessment of marine cyanobacteria Synechocystis and Synechococcus. Mar. Drugs, 6: $1-11$.

Ozdemir, G.; Karabay, N.U.; Dalay, M.C.; Pazarbasi, B. (2004). Antibacterial Activity of Volatile Component and Various Extracts of Spirulinaplatensis. Phytother. Res. 18: 754-757.

Philip, K.; Sinniah, S.K.; Muniandy, S. (2009).Antimicrobial peptides in aqueous and ethanol extracts from microbial, plant and fermented sources. Biotechnology, 1: 1-16.

Piccardi, R., Frosini, A.,Tredici,R.M, and Margheri, C.M. (2009). Bioactivity in free-living and symbiotic cyanobacteria of the genus Nostoc. J. Appl. Phycol. 12 :543 - 547.

Rippka, R. (1988). Isolation and purification of cyanobacteria. In: Glazer, A.N. (Ed.), Methods in Enzymology. In: Glazer, A.N. (Ed.), Cyanobacteria, 167. Academic Press, San Diego, 3-28.

Rao, M.; Malhotra, S.; Fatma, T.; Rattan, A. (2007). Antimycobacterial activity from cyanobacterial extracts and phytochemical screening of methanol extract of Hapalosiphon. Pharm. Biol. 45: 88-93

Shanab, S. M. M . (2007). BioactiveAllelochemical Compounds from Oscillatoria Species (Egyptian Isolates).Int. J. Agric. Biol., 9(4): 617-621.

Tan, L. T. (2007). Bioactive natural products from marine yanobacteriafor drug discovery. Phytochemistry, 68: 954-79.

Thillairajasekar, K.; Duraipandiyan, V.; Perumal, P.; Ignacimuthu, S. (2009). Antimicrobial activity of Trichodesmiumerythraeum 
(Ehr.)(microalgae) from South East coast of Tamil Nadu, India. Int. J. Integr. Biol. 5 (3): 167-170.

\section{مواد مضاده للبكتريا من مستخلصات مختلفه من الطحالب الخضراء المزرقة}

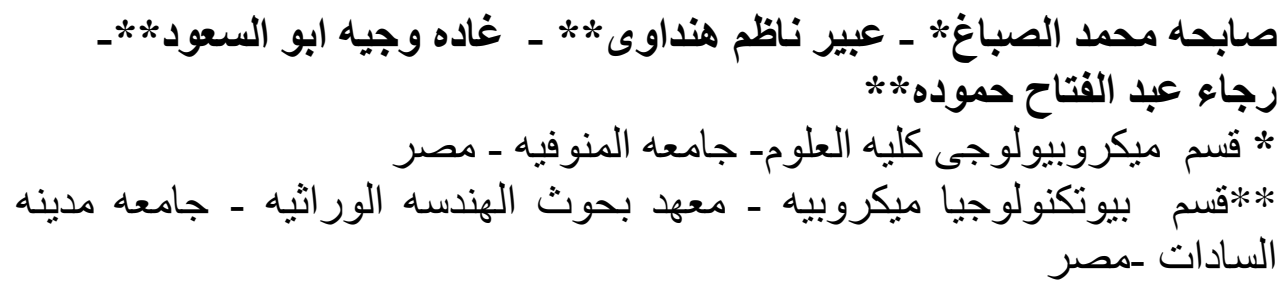

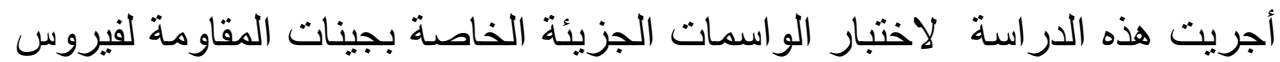

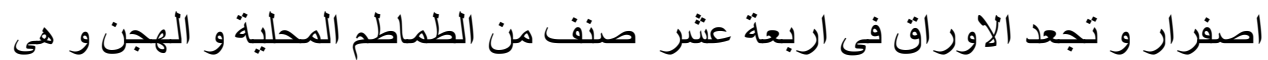
Jubilee, Peto 86, Super Strain B, Advanteg, Edkawi , Super Bader, Tempo(LA 2050), Azteca, G.5, G.S, Nada, 9062, 9065 and 9064. تم زراعتها فى الحقل المفتوح و الصوبة وتم عمل فحص لجين TY2 المقات المقاوم

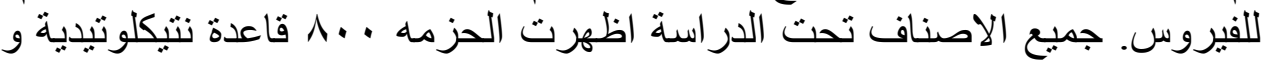

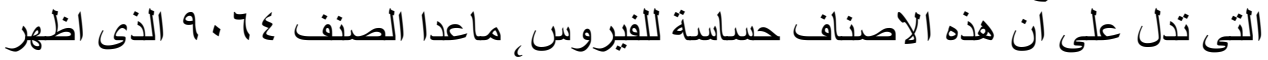
الحزمة . . 1 قاعدة و . . 9 قاعدة نيكلوتيدية و اللتان تدل على ان هذا الصنف مقاوم

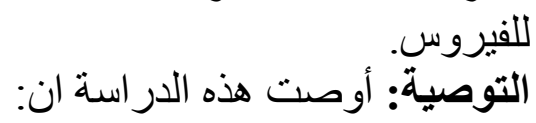
* استخدام طرق الواسمات الجزيئية للتعرف على التى الأصناف المقاومة و الحساسة

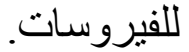

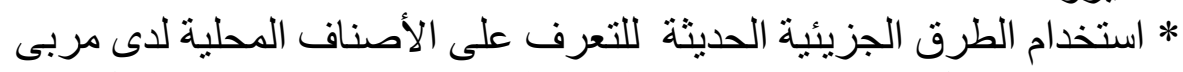
النبات و ذلك قبل إدخالها فى برامج التربية لتوفير الوقت و الجهد و المال. 